\title{
Correction to: The Network of Neighborhoods and Geographic Space: Implications for Joblessness While on Parole
}

\author{
Adam Boessen ${ }^{1}$ · John R. Hipp ${ }^{2}$
}

Published online: 28 April 2021

(C) Springer Science+Business Media, LLC, part of Springer Nature 2021

\section{Correction to: Journal of Quantitative Criminology https://doi.org/10.1007/s10940-021-09510-z}

The original version of this article unfortunately contained a mistake. One of the author "Adam Boessen" affiliation was incorrect. The affiliation is corrected in this correction.

The original article has been corrected.

Publisher's Note Springer Nature remains neutral with regard to jurisdictional claims in published maps and institutional affiliations.

The original article can be found online at https://doi.org/10.1007/s10940-021-09510-z.

Adam Boessen

boessena@umsl.edu

John R. Hipp

john.hipp@uci.edu

1 Department of Criminology and Criminal Justice, University of Missouri St. Louis, 531 Lucas Hall, One University Blvd., St. Louis, MO 63121, USA

2 Department of Criminology, Law and Society, Department of Sociology, University of California, Irvine, 3311 Social Ecology 2, Irvine, CA 92697, USA 